\title{
Avoidable maternal mortality as social injustice
}

Reginaldo Antônio de Oliveira Freitas-Júnior 1

https://orcid.org/0000-0002-2932-2535

1 Centro de Educação e Pesquisa em Saúde Anita Garibaldi. Instituto de Ensino e Pesquisa Alberto Santos Dumont. Rodovia RN 160, 2010. Macaíba, RN, Brasil. CEP: 59.280-000. E-mail: reginaldofreitasjr@gmail.com

\begin{abstract}
Safe motherhood is not a reality for many women and maternal mortality persists as a severe public health problem. This paper aims to discuss avoidable maternal mortality beyond health issues emphasising on human rights violations and the multiple social repercussions on this complex phenomenon. From the human rights perspectives, avoidable maternal death can be characterized as violation of rights related to life, freedom and the person's safety, family life, equality and non-discrimination, as well as to the highest attainable standard of health and benefits from scientific progress. When reproductive health risks are faced by pregnant women, they are not restricted to inherent issues such as pregnancy but they reflecton issues strongly linked in the need of gender equality and empowerment for all women and girls, and avoidable maternal mortality should be understood by everyone as a serious injustice tha tdiscriminates women and violates their fundamental rights. The avoidable maternal death recharacterisation, beginning from health disadvantage to social injustice, should develop a collective critical awareness involving the population, giving visibility repercussions for the individual, the family and the population, as well as promoting new interdisciplinary possibilities in coping, sharing and focusing on social control in public policies.
\end{abstract}

Key words Maternal mortality, Human rights, Women's rights

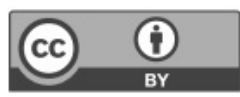




\section{Introduction}

Maternal mortality is an indicator of a population's living conditions and health care and it also reflects on human development of a country. Low levels of schooling, inadequate nutritional conditions, insufficient social support and the lack of access for healthcare are strongly associated with maternal deaths. In addition, maternal mortality is usually the main indicator of differential mortality between the richest and the poorest population, among nations, social groups and families. In this scenario, the acceleration of maternal mortality reduction has been established as one of the global priority targets in the United Nations Sustainable Development Goals. ${ }^{1}$

Avoidable maternal mortality and related to the quality in obstetric care persists as a severe public health problem. Such deaths are not randomly distributed among women and reveal inequity of the population in which they occur, since they are concentrated in developing countries, mainly affecting black women with lower income and lower schooling levels. In Brazil, it is important to note that advances have been observed in the last decades, especially regarding the population's access to basic healthcare. However, when analyzing the indicators on avoidable maternal mortality, the strategies that were used have shown to be little effective.2,3

For the Public Health System (SUS) to strengthen itself in reducing avoidable maternal mortality, need to develop a "collective critical awareness" on the multiple social repercussions of maternal death. The high rates on maternal mortality, which are known to be preventable through the effective health interventions, should be pointed out as a result of social injustice that women suffer due to their social status and which represent a blatant violation of their fundamental human rights. This recharacterisation, from health disadvantage to social injustice, can possibly make a greater visibility to the problem and promote new strategies in coping with health managers, professionals from different areas and ultimately, the whole population.

It is not normal to die of a childbirth. Motherhood is not a disease and therefore, much caution is needed when comparing maternal mortality with other health problems. Maternal death is a sentinel event, an important marker in the quality of the health system, especially in relation to the access, adequacy and care, closely related to the population's social vulnerability. In Brazil, the discussion on avoidable maternal mortality needs to go beyond health issues and strategies in coping need to evoke a reconstructive perspective in care. Maternal health care must overcome individualist conformation, towards collective, institutional and structural spheres of intervention and enrich biomedical rationality in constructs of other sciences and knowledge. 4

The interdisciplinary approach allows to demonstrate that the reproductive health risks faced by women are not simple inevitable misfortunes or disadvantages inherent at pregnancy, but rather injustices that the population has a duty to solve through their political, legal and health systems. Thus, there is a need for an expanded discussion on this complex social phenomenon, adding a multiplicity of views and seeking a coalition of forces for the States to fulfill their duties to protect lives and provide safety for motherhood. This paper aims to discuss avoidable maternal mortality beyond health issues emphasising the violation of human rights and the multiple social repercussions of this complex phenomenon.

\section{Avoidable maternal mortality under the lens of human rights}

After the approval of the Universal Declaration of Human Rights in 1948, its principles were translated into treaties, including the 1979 International Convention on the Elimination of All Forms of Discrimination Against Women. The compliance with the Convention is monitored by the Committee on the Elimination of Discrimination against Women (CEDAW) and its General Recommendation No. 24 postulates that neglecting access to necessary health services for only women is a form of discrimination. 5 Obstetric services with low quality standards, lack of beds or inadequate distribution constitute violations of women's right to equity and care. 6 The Conference on "Safe Motherhood", held in Nairobi in 1987, was a result of an international recognition on maternal death, as a tragedy that needed to be addressed worldwide. 6 Three years later, the Pan American Health Organization's (PAHO) Regional Plan of Action for the Reduction of Maternal Mortality was launched, and then the United Nations International Conference on Population and Development was held in Cairo, when the definition of "reproductive health" was noted and the right to have adequate access to healthcare and services ensured for the pregnancy and childbirth safety. ${ }^{7}$

The $4^{\text {th }}$ World Conference on Women held in Beijing in 1995 reaffirmed the right of women to enjoy the highest standard of health and to obtain control over their reproductive lives and fertility. It 
was recommended that reproductive responsibility should be shared with men, which could mean an improvement in women's health. Despite these efforts, at the end of the 1990 s, maternal mortality rates had not yet declined. 8

In 2000, countries around the world agreed on the Millennium Development Goals (MDGs), assumed a goal to reduce maternal mortality by three quarters. Despite the consensus on the maternal death injustice, the MDG evaluation report points out that this was the goal of less progress, so maternal death continues to reach thousands of women annually. ${ }^{2}$ In Brazil, the goal of the MDGs was to reduce maternal mortality by 2015 , and the value was equal to or lower than 35 deaths per 100,000 live births (LB), which this was not achieved. Although, Brazil ranked at seventh position among the richest countries in terms of Gross Domestic Product, Brazil still ranked at 54th in terms of per capita income. ${ }^{9}$ Countries considered to be poorer or at similar levels of development as Brazil, have lower numbers of maternal mortality, such as Chile (25 deaths/100,000 LB), Uruguay (29/100,000 LB) and Costa Rica (40/100,000 LB). Even Gaza Strip, involved in a permanent war situation and with a per capita income almost five times lower than Brazil, has a Maternal Mortality Ratio (MMR) of 64/100,000 LB, very similar as to Brazil.9,10

The new Sustainable Development Goals (SDG) represent the global initiative that succeeds the MDGs and convene the world for the elimination of the avoidable maternal mortality by 2030 , with the goal of reducing the global MMR to less than $70 / 100,000 \mathrm{LB}$. Considering that the global MMR is currently around $210 / 100,000 \mathrm{LB}$, an effort that all countries need to reduce at least two-thirds of the MMR will be necessary, which for in Brazil means reducing the MMR to approximately 20/100,000 LB. Thus, it is necessary to consider the changes that have occurred in the profile of the obstetric population and maternal mortality, including the reduction of fecundity, aging, excessive medicalisation and the increase of chronic degenerative diseases. ${ }^{3}$

Contrasting with the whole apparatus of international legislation and agreements, there are so few legal cases that have come to courts requiring governments to take the necessary measures to identify the causes of maternal mortality and to take preventive measures to avoid repetition of such damages, such as the violation of rights that ends an preventable maternal death. 11

The challenge of applying the lens of human rights in coping with the avoidable maternal mortality can be understood by referring to the historical transition of thought that considered slavery as part of the natural order of human society, for the characterization of slavery as a very severe violation of a fundamental human right. If slavery engendered sentimental structures and standards of public morality incompatible with the normative demands of a decent society, ensuring safe motherhood, as well as overcoming racism, it is a necessary transformation that certainly threatens the status quo and questions the social value systems.

Obviously, it does not make sense for the States to oppose safe motherhood, and we will never witness the officialization of this type of state positioning, however, the issue that needs to be strongly opposed is that, very often, public managers themselves consider the circumstances that condition avoidable maternal mortality as part of the natural order, including subordination, women's lack of power and their exclusion from the main political, religious, and economic institutions that make decisions in their population.

After 70 years of the promulgation of Human Rights and almost 20 years after the universal acceptance of the millennium goals, the need remains to characterize human rights that keep being violated in terms of avoidable maternal mortality:

\section{Rights relating to life, freedom and the person's safety}

The International Covenant on Civil and Political Rights, 12 on its Article 6, establishes that "the right to life inheres in every human being". Thus, the protection of the right to life should not be narrowly understood in the sense that governments should avoid arbitrary executions and death penalty, but rather have a broader view that allows the State to adopt positive and protective measures to guarantee the right to life, including to prevent avoidable maternal mortality, such as ensuring accessibility to health services, including emergency obstetric care. The State should ensure that health workers receive adequate training, strengthen family planning and sex education programs, and ensure that women are not forced to undergo unsafe abortions. Specially, a greater attention should be given to the effects of restrictive abortion legislation on women's health. 5

The person's rights to freedom and safety have been applied by at least a dozen national constitutional courts in cases of abortion to ensure women's freedom to decide whether, when and how often to have children.13,14 By challenging our justice systems to apply these rights to advance safe motherhood, we can begin by explaining to health professionals that the factors that put a woman at 
risk of maternal mortality deny the right for her safety and if governments and the health systems fail to provide the conditions that allow women to control their fertility, have a voluntary pregnancy and a safe childbirth, they are responsible for violating women's right, and should take the necessary steps to avoid and remedy this situation.

\section{Rights regarding family life}

Although the right to marry and to form a family is well protected, there is the lack of legal protection for a woman's expectation to survive a pregnancy. Until the settlement of Alyne da Silva Pimentel Teixeira (deceased) versus Brazil, no government had been held responsible for cases of avoidable maternal mortality before National or International courts or agencies. 11

Respect for women's human dignity there should include the ability to survive pregnancy and childbirth. Biology characterizes the formation of human life with women generating, nourishing, protecting and promoting the development of their children before birth and they are the ones who bring them to life. Surviving gestation and childbirth are of fundamental premise for women to guarantee human rights in relation to family life.

\section{Rights relating to the highest attainable standard of health and the benefits of scientific progress}

The necessities related to maternal health need to be understood according to the conception of health needs as a structuring concept in the struggle for integrality and equity in care. 15 The identification of hypertension, hemorrhages and infections as the main causes of avoidable maternal mortality and the availability of therapeutic strategies for its control have not been effective for solving the problem. The question is that having access to the highest attainable health level and the benefits of scientific progress represents an unfulfilled need to achieve safe motherhood.

Studies indicate that the time to obtain adequate care is considered the most important factor related to maternal deaths. Delays between the onset of a complication and its appropriate treatment or outcome may occur in three phases: phase I - delay in the decision to seek care by the individual and/or family; phase II - delay in the access to an appropriate health care unit; and phase III - delay in receiving appropriate care at the referred institution. 16 The concept of "three delays" unifies diverse factors, including women's autonomy, geographic distance and access for care, evoking various areas of knowledge, such as anthropology, social sciences and geography, and provides a clear theoretical framework for the study on avoidable maternal mortality. ${ }^{17}$ However, all the delays are interrelated, since most maternal deaths cannot be attributed to a single delay, more commonly a combination of factors.

In the dimension of highlighting the causal, social and behavioral sequence, related to the family, community and health system in a single theoretical framework, the scientific method currently used to study maternal mortality starts to co-operate with the perspective that, whatever the delay is, it also violates its victims the rights relating to the highest attainable standard of health and the benefits of scientific progress, including health information and education.

\section{Rights regarding equality and non- \\ discrimination}

The greatest threat to women's reproductive health is their inability to practice their rights to equality. Sexual discrimination is often aggravated by discrimination based on marital status, race, age and class, which often makes young women with low socioeconomic status and minority racial groups more vulnerable to maternal mortality risk. In their communities, women do not enjoy the same status and importance that men enjoy. 18

Equality requires that we should treat each other with the same interests without discrimination, such as the access of people of both genders to schooling, but we also treat different interests appropriately in order to respect such differences, such as the specific interests of women as to pregnancy and childbirth safety. The rights to equality are violated when they disregard the fundamental biological difference between men and women, which, year after year, hundreds of thousands of women die unnecessarily.

Men and women are equal and co-dependent partners of the human race and the biological difference between them should not be invoked as a justification for treating women as a different and inferior species. Even so, the biological difference is critical regarding motherhood and maternal mortality. ${ }^{11}$

The demeaning social injustice that contemporary societies are obliged to correct is that they discriminate against women in aspects where gender differences should never matter, such as access to education, culture, political and economic opportunities, by simply ignoring the difference where it would need to be much more recognized and valued, especially in the need for special care for maternal 
health and on avoidable maternal mortality prevention.

It seems clear to us that Brazilian democracy, still young and deficient in achieving the universal citizenship, lacks a "cultural citizenship". It lacks cultural policies that are able to promote the release of the shame and humiliation of the vast majority of women who are poor and expropriated from social rights. We need education in a broad sense, not merely formal, focused on literacy and vocational training, but this takes into account the quality of teaching and content conveyed by the mass media, stimulating public debate, allowing the empowerment of individuals being a catalyst for citizenship, especially the lower social class women.

The experience of an improvement in life, no matter how little it is, it deeply engraves in people's souls, rescues their dignity and opens their world to the emergence of greater libertarian demands. A right expands and gives rise to new claims for other rights and thus indefinitely, a true virtuous circle of rights.

\section{For a "collective critical awareness"}

The efforts in reducing avoidable maternal mortality should include actions at all levels, with the active participation of society, governments, service providers and, of course, the institutions that make up the professionals who should care for women's health. Such actions should cover the organization of network assistance, with early universal barrier-free access to obtain prenatal care with quality and have guaranteed assistance at a referred maternity previously defined and known by the woman.

The Brazilians' pilgrimage in search of a place to give birth reveals that the adequate structuring and organization of the care services assume strategic importance, including the involvement and training of the professionals, the early recognition of problems and timely and effective action in facing complications that threatens these women's lives. However, there is much more to be done. For the population to embrace the reduction of avoidable maternal mortality as a priority cause, it is necessary that the problem be given greater visibility and be widely discussed among the most different social actors should emphasis on the social dimensions of maternal death, the gender perspective intrinsically related to the violation of human rights and the moral imperative coping with the problem must represent human dignity and the collective construction of citizenship.

Health professionals, who have in SUS an autho- rized officer for their training, need to discuss the avoidable maternal mortality besides what is written in the medical records. Professions together need to learn that social repercussions on maternal death produce individual, family, and collective tragedies that magnify and perpetuate the vicious cycle of violation on fundamental rights and guarantees. Health professionals' education should ensure discussion on the determinants and social consequences of maternal mortality during vocational training, incorporating the interprofessional perspectives in approaching the theme and including social sciences. It is necessary to broaden the horizons of these professionals' perception on the severity contained in the avoidable maternal mortality and the importance of their role as social transformation agents to guarantee safe motherhood as a constituent element of social justice.

Popular health education actions need to discuss avoidable maternal mortality with health system users and also seek to reach citizens' understanding of the magnitude of the social problem it represents and its importance as an indicator of the health status of a given population. Likewise, health education should foster the development of personal potential and the expansion of autonomy, in order to provide adequate conditions for people to make competent choices, including their sexual and reproductive health. Men and women need to be aware what is contained in the submerged part of this iceberg, as cold as the indifference of the population that ignores it.

It is urgent to fight against the unconscious collective that accepts maternal death as the heroic fate of the woman who gives her life to her child, an irreducible risk inherent in every pregnancy or even resigned to the will of a masculine God who knows all. There is no deity, just as fair as it is able to demand from a woman such sacrifice. Maternal death from preventable causes must be understood by all citizens as unacceptable.

It is necessary to foster the development of a "collective critical awareness" that rejects, repudiates, becomes indignant and revolts against woman's death, due to the poor quality of obstetric care provided. To provoke this indignation is a central issue to transform social attitudes towards the violation of human rights of women dying at childbirth.

In order to achieve "collective critical awareness" about the real cost of maternal death, it is necessary to disclose the immediate and late effects of this death at homes, the newborn's life, the surviving children, the closest family members, and even the community that the woman was part of. 
Although, many are reluctant to admit or even insist on ignoring the expanded analysis on the social impacts of maternal mortality allowing us to emphasize the centrality of the mother's role in our society. In the context of the divisions constituting the social order and, more precisely, the social relations in dominating and exploiting that are established between genders, the woman/mother is truly the center of the home, of the reproduction, of the family's social relations, manager of the house budget, responsible for the children's socialization, guardians of the morality, education and health. 19 Thus, as the current population still see the division of roles between the genders from the point of view of the "order of things"; to speak of what is normal, natural, to the point of being, even, inevitable, in what Bourdieu nominated as the insertion of a system in the homologous oppositions; when the mother of the family dies, all functions related to her role invariably die somewhat as well. Not infrequently are the histories in which many other people are needed, regardless of their gender, to handle all for the multiplicity of activities previously performed by the single mother who is now gone.

This is not a matter of introducing a reinforcement to the subjective and objective needs of the division of things and activities, sexual and of all other, according to the opposition between masculine and feminine, nor is the denial of pertinent and complementary oppositions between the two "essences" but rather to recognize in a current scenario, maternal death brings an important social repercussions that deserve visibility and awareness on behalf of the whole population.

An international literature brings data that explain the issue in a very sensitive way. A longitudinal study, conducted in Ethiopia between 1987 and 2011, examined the consequences of maternal mortality on children's survival. The results observed during these 25 years show the strong association between the mother's death and the surviving children's death. As the study tracked these individuals over the long term, the late consequences were also very concerning. There was a significant propensity for non-education and poverty, with greater risks for the repetition in the history of maternal and neonatal mortality in their lives. ${ }^{20}$

Another study found that orphan children have a significant reduction in healthcare, with lower immunization rates, and access to medical care when they become ill. It was also found that parents rarely assume the roles culturally attributed to the female gender, such as the responsibility for caring for the children, caring for the home, cooking and gener- ating extra income. It is common for older children in the family, especially girls, to drop out of school to take up maternal roles. ${ }^{21}$

In Malawi, East Africa, Bazile et al.22 found that the loss of a mother profoundly aggravated the survival and vulnerability of the children to illness and malnutrition, shortened school time and increased school dropouts, inserted into job market, marriage and parenthood too early. When orphans are adopted by relatives, most of whom are also very poor, the addition of another child to subsistence living conditions can create tensions, health and education issues between natural and adoptive children. If the father assumes a new wife, the children of the dead woman are often treated as second-class citizens, deprived of food, comfort, healthcare and education, which is now a priority for the new woman's offspring. 22

There are important publications from different continents, making clear the relationship between maternal morbidity/mortality and neonatal health, showing how pregnancy and childbirth complications affect the survival of newborns, increasing the risk of fetal and neonatal death. 3,23

The child whose mother died at childbirth is exposed to a greater risk of nutritional problems due to lack of breastfeeding, the consumption of contaminated water or inadequate artificial foods, a higher mortality risk, and a higher chance of infection, growth and development deficit.24,25 Older children, especially girls, often suffer from dropping out of school early, poverty, exposure to various forms of violence, including sexual violence, early marriage and motherhood, thereby perpetuating the disastrous cycle which result in avoidable maternal mortality.

The issue on the avoidable maternal mortality should mobilize minds and hearts, provoke humanization initiatives and expressions of indignation against the scenario of discrimination and institutional violence in Brazil; it should result in individual actions and advocacy groups for human rights, feminists, and sexual and reproductive health, that is, of each individual and institution that views human rights, not as rhetorical discourse, and merely normative, but with political content, libertarian and emancipatory potential, able to promote social transformation and change certain reality and practice, within ethical, philosophical and legal frameworks, and within a vision of the world that enables to achieve women's life projects, guaranteeing them the right to a free life of avoidable maternal mortality. 26 


\section{Considerations not intended to be concluded}

Neglect the quality of maternal health services, once exclusively used by the female population, entails the explicit discrimination against women, which can be recognized as a violation of principles of equal rights and the respect for human dignity, and also as a hinderance for women's participation in the population's life in equal conditions as to men. The avoidable maternal mortality can be seen as a result of human rights violation, and this approach makes it possible to explain to the population that it is not a natural phenomenon that is distributed at random. It also allows us to affirm that the State has an obligation to respect, protect and provide these rights.

Integrality in maternal healthcare is a principle with multiple meanings, which points to a universe of values for which uncompromising struggle is necessary, since they are intimately involved in building a more fair, human and supportive society. Women's death due to pregnancy, childbirth and puerperium greatly transcends biological facts and is certainlydetermined by their living conditions and their social participation. Women exposed to high risk of dying from preventable causes are subjects, have a life history, have knowledge and, above all, have rights. To listen, speak and allow others to speak, dialoguing and trying to understand these women's necessities, in a much more comprehensive way, is a sine qua non condition to provide inte- grality and equity in the reproductive healthcare.

Sensitizing public opinion on different prisms through which the horrified image of maternal death can be seen, represents a valuable resource so that the "collective critical awareness" on the magnitude of this problem is able to transform rhetoric actions into effective actions in coping with the reality that we see.

The visions of human and social sciences on the issue constitute dialogic interfaces with great potential (trans)formation of social awareness in the health workers for the effectiveness of care in maternal health. From this perspective, avoidable maternal mortality is usually characterized as a health disadvantage, it needs to be understood as a social injustice that discriminates against women and violates their human rights. This transformation should involve all segments of society, giving visibility to the individual, family and collective repercussions and promoting new perspectives in coping, interdisciplinary, which are shared and focused on social control in public policies.

\section{Author's contribution}

Freitas-Júnior RAO performed conception and design, data collection, analysis and interpretation of data, writing of the article. The author approved the final version of the article.

\section{References}

1. Osanan GC, Padilha H, Reis MI, Tavares AB. Strategy for Zero Maternal Deaths by Hemorrhage in Brazil: A Multidisciplinary Initiative to Combat Maternal Morbimortality. Rev Bras Ginecol Obstet. 2018;40: 103-5.

2. PNUD (Programa das Nações Unidas para o Desenvolvimento). Relatório Nacional de Acompanhamento dos Objetivos do Milênio. 2014 [acesso 3 dez 2017]. Disponível em: http://www.pnud.org.br/ Docs/5_RelatorioNacionalAcompanhamentoODM.pdf

3. Souza JP. A mortalidade materna e os novos Objetivos de Desenvolvimento Sustentável (2016-2030). Rev Bras Ginecol Obstet. 2015; 37: 549-51.

4. Ayres JR CM. Cuidado e reconstrução das práticas de Saúde. Interface - Comun Saúde Educ. 2004; 8 (14): 73-92.

5. United Nations. Convention on the Elimination of All Forms of Discrimination against Women. Committee on the Elimination of Discrimination against Women. Views of the Committee on the Elimination of Discrimination against Women under article 7, paragraph 3, of the Optional Protocol to the Convention on the Elimination of All Forms of Discrimination against Women (forty-ninth session) 2011. [acesso 26 fev 2019]; Disponível em: http://www.worldcourts.com/cedaw/eng/decisions/2011.07.25_da_Silva_Pimentel_v_Brazil.pdf

6. Reis LGC, Pepe VLE, Caetano R. Maternidade segura no Brasil: o longo percurso para a efetivação de um direito. Physis Rev Saúde Coletiva. 2011; 21 (3): 1139-60.

7. Den Exter A. International Health Law \& Ethics. 2 ed. Antwerpen: Maklu; 2011.

8. Den Exter A. Human Rights And Biomedicine. Antwerpen: Maklu; 2014.

9. The World Bank. World Development Indicators. 2013 [acesso 3 dez 2017]. Disponível em: http://databank.worldbank.org/data/home.aspx

10. WHO (World Health Organization). Trends in maternal mortality: 1990 to 2010 The World Bank WHO Library Cataloguing-in-Publication Data. WHO Libr Cat; 2012. [acesso 3 dez 2017]. Disponível em: http://www.who.int/ about/licensing/

11. Cook RJ. Human Rights and Maternal Health: Exploring the Effectiveness of the Alyne Decision. J Law Med Ethics. 2013; 41 (1): 103-23.

12. Brasil. Pacto Internacional Sobre Direitos Civis e Políticos. 
1992 [acesso 3 dez 2017]. Disponível em: http://www.planalto.gov.br/ccivil_03/decreto/19901994/d0592.htm

13. ONU (Organização das Nações Unidas). Relatório da Conferência Internacional sobre População e Desenvolvimento -Plataforma de Cairo; 1994. [acesso $3 \mathrm{dez}$ 2017]. Disponível em: http://www.unfpa.org.br/Arquivos/ relatorio-cairo.pdf

14. Corte Interamericana de Derechos Humanos. Caso Velásquez Rodríguez Vs. Honduras. Sentencia de 29 de julio de 1988. [acesso 26 fev 2019]. Disponível em: http://www.corteidh.or.cr/docs/casos/articulos/seriec_04_es p.pdf

15. Cecílio LCO. As necessidade de saúde como conceito estruturante na luta pela integralidade e equidade na atenção. In Os sentidos da integralidade na atenção e no cuidado à saúde [Internet]. ABRASCO. Rio de Janeiro; 2001 [acesso 3 dez 2017]. Disponível em http://www.uff.br/pgs2/textos/Integralidade_e_Equidade_n a_Atencao_a_saide_-_Prof_Dr_Luiz_Cecilio.pdf

16. Thaddeus S, Maine D. Too far to walk: maternal mortality in context. Soc Sci Med. 1994; 38 (8): 1091-110

17. Kalter HD, Salgado R, Babille M, Koffi AK, Black RE. Social autopsy for maternal and child deaths: a comprehensive literature review to examine the concept and the development of the method. Popul Health Metr. 2011; 9: 45.

18. Cook R. A dimensão dos direitos humanos na mortalidade Materna. In: Consulta Técnica sobre Questões da Maternidade Segura: Dez Anos de Lições e Progressos. Colombo; 1997. p. 18-23.

19. Bourdieu P. A dominação Masculina. Tradução Maria Helena Kuhner. 2 ed. Rio de Janeiro: Bertrand Brasil; 2002.

20. Moucheraud C, Worku A, Molla M, Finlay JE, Leaning J, Yamin A. Consequences of maternal mortality on infant and child survival: a 25-year longitudinal analysis in Butajira Ethiopia (1987-2011). Reprod Health. 2015; 12 (Suppl. 1): S1-S4.

Received on February 27, 2019

Final version presented on July 22, 2019

Approved on March 30, 2020
21. Molla M, Mitiku I, Worku A, Yamin A. Impacts of maternal mortality on living children and families: A qualitative study from Butajira, Ethiopia. Reprod Health. 2015;12 (Suppl. 1): S6.

22. Bazile J, Rigodon J, Berman L, Boulanger VM, Maistrellis E, Kausiwa P, Yamin AE. Intergenerational impacts of maternal mortality: Qualitative findings from rural Malawi. Reprod Health. 2015; 12 (Suppl. 1): S1.

23. Pande R, Ogwang S, Karuga R, Rajan R, Kes A, Odhiambo FO, Laserson K, Schaffer K. Continuing with "...a heavy heart" - consequences of maternal death in rural Kenya. Reprod Health. 2015; 12 (Suppl. 1): S2.

24. Kusiako T, Ronsmans C, Van der Paal L. Perinatal mortality attributable to complications of childbirth in Matlab, Bangladesh. Bull World Health Organ. 2000; 78 (5): 621-7.

25. Vogel J, Souza J, Mori R, Morisaki N, Lumbiganon P, Laopaiboon M, Ortiz-Panozo E, Hernandez B, PerezCuevas R, Roy M, Mittal S, Cecatti JG, Tunçalp O, AM Gülmezoglu AM, on behalf of the WHO Multicountry Survey on Maternal and Newborn Health Research Network. Maternal complications and perinatal mortality: findings of the World Health Organization Multicountry Survey on Maternal and Newborn Health. BJOG An Int J Obstet Gynaecol. 2014; 121: 76-88.

26. Galli B. Mortalidade materna e direitos humanos: as mulheres e o direito de viver livres de morte materna evitável. Rio de Janeiro: Advocaci; 2005. 